ljtihad, Jurnal Wacana Hukum Islam dan Kemanusiaan

Vol. 17, No. 2 (2017), pp. 191-215, doi : 10.18326/ijtihad.v17i2. 191-215

\title{
Dekonstruksi paradigmatik pengembangan zakat: analisis kritis pemikiran Yusuf al-Qaradawi
}

\author{
Jamal Abdul Aziz \\ Institut Agama Islam Negeri (LAIN) Purvokerto \\ Jl. Jend. Abmad Yani No. 40A Purwokerto \\ E-mail:abdulazizjamal314@yaboo.co.id \\ DOI: 10.18326/ijtibad.v17i2.191-215
}

The construct of the argument for the development of zakat treasures in the thought of Yusuf alQaradawi can be divided into two general and special ones. The general argument is based on the theory of qiyas and maslahah, while the specific argument is based on the theory in the jurisprudence of zakat itself, that is with respect to the criteria of zakat property. From the six criteria he mentioned he then developed one of them is a productive (growing) property. On the basis of these criteria then many new types of treasures that can be covered into zakat property, such as the treasures obtained from company stock, honey, and profession. Of course the new treasures he mentioned just as an example only. In the future it can continue to grow in accordance with the development of Muslim life. The argument for the development of zakat property can be contradicted by three arguments: ambiguity in placing the doctrine of zakat between the teachings of mahdah worship and the teachings of muamalah / 'adah (worldliness); tend to separate the study of zakat from the historical context in which the obligations of zakat in the time of the Prophet and the caliph after him are always related to the life of the state / government; and stressing that the zakat is different from the taxes is basically a result of its ambiguity in looking at zakat.

Konstruk argumen pengembangan cakupan harta zakat dalam pemikiran Yusuf al-Qaradawi dapat dibedakan menjadi dua yakni yang bersifat umum dan khusus. Argumen umumnya didasarkan atas teori qiyas dan maslahah, sementara argumen khusus didasarkan pada teori dalam fikih zakat itu sendiri, yakni yang berkenaan dengan kriteria harta zakat. Dari enam kriteria yang ia sebutkan ia kemudian mengembangkan salah satunya yakni harta yang produktif (berkembang). Atas dasar kriteria ini maka banyak harta jenis baru yang bisa tercakup menjadi harta zakat, seperti harta-harta yang diperoleh dari saham perusahaan, ternak madu, dan profesi. Tentu saja harta-harta baru yang ia sebutkan sekedar sebagai contoh saja. Di masa yang akan datang dapat terus bertambah sesuai dengan perkembangan 
ljtihad: Jurnal Wacana Hukum Islam dan Kemanusiaan, Volume 17, No. 2, Desember 2017: 191-215

kehidupan umat Islam. Argumen pengembangan cakupan harta zakat tersebut dapat disanggah melalui tiga argumen: ambiguitas dalam menempatkan ajaran tentang zakat antara ajaran ibadah mahdah dan ajaran muamalab/'adah (keduniaan); cenderung memisahkan kajian zakatnya dari konteks historis di mana kewajiban zakat di masa Nabi dan para khalifah sesudahnya selalu terkait dengan kehidupan kenegaraan/pemerintahan; dan penekanan bahwa zakat berbeda dengan pajak pada dasarnya akibat dari ambiguitasnya di dalam memandang zakat.

Keywords: productive property; bistoricity of zakat; normativity of zakat; tax, country income

\section{Pendahuluan}

Isu paling aktual dan sekaligus krusial berkenaan dengan ajaran Islam tentang zakat adalah mengenai pengembangannya, baik dalam aspek sumber atau harta yang wajib dizakati maupun dalam aspek pengelolaannya. Jika ditelusuri dari sudut pandang teori hukum Islam pengembangan ajaran zakat sesungguhnya memunculkan problem paradigmatik. Di satu sisi ajaran tentang zakat yang pada umumnya dipersepsikan sebagai ibadah mahdab lazimnya tidak bisa dikembangkan, sebagaimana ajaran-ajaran ibadah tentang salat, puasa, dan haji. Ibadah-ibadah mahdah semacam ini memiliki karakter taken for granted (terima jadi), unintelligible (ghayr ma'qulah al-ma'na), dan tertutup terhadap perubahan (kreasi dan inovasi) (Aziz, 2009: 98-106). Jika pengembangan salat, pengembangan puasa, pengembangan haji merupakan hal-hal yang tidak lazim berdasarkan karakter ibadah mahdah tersebut maka demikian pula semestinya dengan pengembangan zakat. Oleh karena itu zakat dalam perspektif teori ini dipandang sebagai ajaran hukum ibadah yang yang tidak bisa menerima perubahan, penambahan, maupun inovasi baru, baik dalam hal harta yang wajib dizakati maupun ketentuan besaran nilainya beserta nisabnya.

Di sisi lain, ajaran tentang zakat yang oleh sebagian ulama saat ini terus dikembangkan dan diperluas cakupannya sesungguhnya lebih tepat dimasukkan dalam kategori 'ádāt/ mu'ämalät. Ajaran-ajaran hukum dalam lingkup 'ádat/mu'amalät memiliki karakter rasional (intelligible, ma'qülah al-ma'nā) dan terbuka terhadap perubahan dan inovasi baru. Ajaranajaran hukum yang termasuk dalam kategori ini pada umumnya adalah ajaran-ajaran hukum yang memiliki dimensi sosial yang kuat. Aturan hukum yang memiliki dimensi sosial yang tinggi menghendaki sifat yang dinamis dan sifat ini hanya mungkin terwujud jika atauran 
hukum tersebut bersifat rasional. Oleh karena itu, dalam perspektif ini, pengembangan cakupan harta zakat sampai kepada zakat madu beserta produk hewani lainnya; zakat pertambangan beserta hasil laut; zakat investasi pabrik, gedung, dan yang semacamnya, zakat profesi; bahkan hingga zakat saham dan obligasi; sebagaimana dimunculkan oleh Yusuf Al-Qardawi (al-Qaradâwî, 1973:1215);tentu saja bisa dibenarkan berdasarkan teori 'àdät/mu'ämalät tersebut.

Di antara kerangka pemikiran yang melandasi Yusuf Al-Qaradawi dalam pengembangan cakupan zakat tersebut adalah teori qiyas dan teori maslahah. Qiyas yang digunakannya adalah qiyas yang benar. Ia tidak membantah pandangan yang menolak penggunaan qiyas dalam ranah ibadah mahdah, seperti salat, puasa, dan haji. Yang ditolak adalah memberlakukan ajaran zakat seperti memberlakukan ibadah mabdah yang menolak pemberlakuan qiyas di dalamnya. Baginya zakat bukan merupakan ibadah mahdah, tetapi kewajiban tertentu, dan bagian sistem keuangan, sosial, dan ekonomi negara di samping memang mengandung nilanilai ibadat; 'illatnya pun secara umum dapat dipahami, oleh karena itu tidak ada alasan untuk tidak menerapkan qiyas dalam mengembangkannya. (Al-Qaradawi, 2011: 28). Ia kemudian menunjukkan beberapa contoh penerapan qiyas yang telah dilakukan oleh para ulama mujtahidin. Di antaranya Imam Syafi'i dan Imam Ahmad ibn Hanbal yang memperluas makna kurma dan gandum pada zakat fitrah dengan semua bahan makanan yang menjadi makanan pokok masyarakat ataupun individu tertentu. Mereka tidak menjadikan jenis-jenis makanan dalam hadis Nabi tentang zakat fitrah tersebut sebagai bentuk ibadat (ta'abbud) yang tidak memungkinkan untuk diqiyaskan. (Al-Qaradawi, 2011: 29)

Adapun teori maslahah yang digunakan oleh Yusuf al-Qardawi mengacu pada teori alSyatibi yang menyatakan bahwa hukum-hukum syariat diundangkan semata-mata untuk kemaslahatan manusia di dunia maupun akherat, baik yang bersifat primer, sekunder, maupun tersier. Dasar dalam ibadat adalah ta'abbud (kepatuhan mutlak) tanpa memikirkan maknanya secara rasional. Sedangkan dasar dalam 'àdāt (mu'ámalät, hukum-hukum non-ibadah) adalah rasionalitas makna. (Al-Qaradawi, 2011: 30). Dalam konteks ini Al-Qaradawi menegaskan kembali bahwa ajaran tentang zakat, kendati seringkali disebutkan beriringan dengan salat dalam fikih ibadah, namun ia bukanlah ibadah murni, tetapi lebih tepat dimasukkan dalam kategori 'ádât/mu'amalàt. Hal itu dikarenakan ajaran zakat berkenaan dengan harta bagi umat 
ljtihad: Jurnal Wacana Hukum Islam dan Kemanusiaan, Volume 17, No. 2, Desember 2017: 191-215

Islam, dalam konteks yang lebih luas ia merupakan hubungan antara negara dengan pemilik harta atau antara pemilik harta dengan fakir miskin di dalam ketiadaan negara. Dasar pandangan tersebut adalah bahwa kitab-kitab fikih yang berkenaan dengan harta dan pemerintahan Islam umumnya memasukkan tema tentang zakat di dalamnya, seperti Kitab al-Kharaj (Abu Yusuf), al-Amwal (Abu Ubayd), al-Ahkam al-Sultaniyyah (al-Mawardi dan Abu Ya'la al-Hanbali), dan al-Siyasah al-Syar'iyyah (Ibn Taymiyyah). Hal itu menunjukkan bahwa zakat sesungguhnya bagian dari sistem pemerintahan dalam Islam. Oleh karena itu dalam pandangannya zakat lebih tepat dimasukkan dalam kategori 'adat/mu'amalät.

Kendati argumentasi pengembangan zakat tersebut pada umumnya dapat diterima oleh para ulama, namun terdapat beberapa titik kritis yang tidak mudah dijawab, khususnya dalam konteks umat Islam di Indonesia. Pertama, jika cakupan harta yang dizakati dapat terus dikembangkan siapa yang memliki otoritas untuk menentukan harta tertentu wajib dizakati sementara yang lain tidak? Bukankah kewenangan mewajibkan atau mengharamkan sesuatu merupakan domain Syari' (Allah melalui Rasul-Nya), dalam konteks keagamaan (Khallaf, 1978: 96-7) atau bisa menjadi domain negara, dalam konteks kewajiban kebendaan.

Kedua, jika ajaran tentang zakat sudah dianggap masuk dalam ranah 'ádatt/mu'àmalat, sehingga bisa terus dikembangkan, mengapa ketentuan teknis tentang kadar, nisab, dan mustahiq zakat masih terus dipertahankan atas nama ibadat, bukankah hal ini menunjukkan ambiguitas pandangan terhadap zakat? Di satu sisi ia dianggap sebagai ajaran 'ádatt/mu'ämalät yang bisa terus dikembangkan, sementara di sisi lain ia juga dianggap sebagai 'ibadat yang tertutup terhadap perubahan dan inovasi. Apa batasan pengembangan atau modifikasi tersebut? Jika kadar, nisab, dan mustahiq zakat dinilai tidak bisa dirubah karena sudah ditentukan dalam nas syarak, bukankah jenis-jenis harta zakat pun juga sudah ditentukan dalam nas syarak juga. Di samping itu jika pengembangan cakupan harta zakat bisa dilakukan melalui ijtihad, apakah berarti juga cakupan harta yang sudah ada bisa dikurangi berdasarkan ijtihad, sehingga akan ada harta yang tadinya wajib dikeluarkn zakatnya kemudian tidak lagi. Pertanyaan-pertanyaan semacam ini akan terus muncul selama cara pandang terhadap ajaran zakat masih bersifat parsial dan ambigu. Parsial dalam arti memahami zakat terlepas dari konteks historis (zakat sebagai semacam pajak) sedangkan ambigu dalam arti tidak tegas memasukkan ajaran zakat dalam ketagori 'ibadat ataukah mu'amalat/'adat. 


\section{Yusuf al-Qaradawi dan corak pemikiran hukum Islamnya}

Syekh Yusuf al-Qaradawi adalah salah seorang pendiri dan sekaligus presiden International Assosiation of Muslim Scholars dan Europian Council for Fatwa and Research. Ia memiliki website sendiri yang cukup terkenal, Islam Online, dalam bahasa Arab dan Inggris. Ia juga memiliki karya yang amat banyak, tidak kurang dari 100 judul buku yang ia tulis tentang Islam dan ajaran-ajarannya. Di kalangan sejawatnya reputasinya dipandang sangat tinggi. Mustafa al-Zarqa', misalnya, menyatakan bahwa memiliki buku al-Halal wa al-Haram fi alIslam merupakan kewajiban bagi setiap keluarga muslim. Sementara Abu al-A'la al-Mawdudi menggambarkan buku Figh al-Zakah merupakan buku dalam bidang hukum Islam paling bagus pada abad ini (abad XX M). Belum lagi pengaruh luasnya dari penampilan berkalanya pada acara al-Syari'ah wa al-Hayah yang disiarkan oleh TV al-Jazeera.(Soage 2008: 51).

Tidak ada kajian akademis-kritis terhadap biografi al-Qaradawi. Informasi mengenai masa kehidupan awalnya sebagian besar bersumber dari dirinya sendiri yang ditulisnya di website yang ia kelola, yakni wnw.islamonline.net (Helfont, 2009: 36).

Yusuf Mustafa al-Qaradawi dilahirkan pada tahun 1926 di bift Turâb, sebuah Desa kecil di tepi Sungai Nil di mana terdapat salah seorang sahabat Nabi yang pernah hidup dan dimakamkan, yakni 'Abd Allah ibn al-Haris, seorang yang ikut dalam penaklukan Mesir (639-641 M). Ayah al-Qaradawi meninggal saat ia baru berumur dua tahun dan ia diasuh oleh ibunya di rumah pamannya, Ahmad, seorang petani miskin yang menganggapnya sebagai anak sendiri. Keluarga al-Qaradawi adalah keluarga yang agamis dan memegang tradisi. Pamannya, Ahmad, rajin salat berjamaah lima waktu di masjid; sementara salah seorang pamannya yang lain adalah penghafal Qur'an. Ia mulai belajar di Kuttab (sekolah Qur'an) bahkan sebelum mulai belajar di sekolah negeri. Di kedua sekolah tersebut ia adalah murid yang cerdas dan sangat rajin. Ia menamatkan hafalan Qur'annya pada usia sembilan tahun di mana pada waktu itu ia mendapat gelar syekh.

Menginjak remaja ia pindah ke Tanta untuk sekolah di Azhari, sekolah setingkat SMP di kota tersebut. Ia sering mendapat ranking satu di kelasnya dan mendapatkan hadiah sedikit uang yang dapat menambahi pendapatannya. Selama di Tanta ia berkesempatan untuk mendengarkan ceramah Hasan al-Banna, pendiri Ikhwanul Muslimin, dan kemudian ia menjadi salah seorang pengikutnya. Pada usia 14 tahun ia dinobatkan sebagai imam masjid 
ljtihad: Jurnal Wacana Hukum Islam dan Kemanusiaan, Volume 17, No. 2, Desember 2017: 191-215

di desanya. Hubungannya dengan Ikhwanul Muslimin membuatnya aktif berdakwah di desa-desa lainnya di tepi Sungai Nil untuk membimbing masyarakatnya, menguatkan keimanan mereka, meluruskan paham keagamaan mereka, dan mengembangkan nilai-nilai dan perilaku mereka sesuai dengan tuntunan agama. Ketika berumur 20 tahun ia mulai mengajar fikih di desanya. Menurut penuturannya sendiri pelajaran yang diberikannya dibentuk oleh tiga nilai yang kemudian mendasari pandangan fikihnya di masa mendatang, yakni: membumi (relevan), toleran (tasamuh), dan bebas dari ikatan mazhab fikih.

Ia pernah bekerja sebentar di Kementerian Wakaf. Ia juga bekerja di divisi kebudayaan pada Universitas al-Azhar dan pada tahun 1962 ia dikirim ke Qatar untuk mengelola perwakilannya di sana. Di Doha ia mendirikan Divisi Kajian Islam (Department of Islamic Studies) dan Fakultas Hukum Islam dan Kajian Islam (Faculty of Islamic Law and Islamic Studies) pada institut keguruan (Teacher Training College). Pada tahun 1973 ia mendapatkan gelar doktornya dari al-Azhar dengan disertasi "Peran Zakat dalam Mengatasi Masalah Sosial." Semenjak itu ia telah menulis banyak sekali buku, aktif berperan dalam pendirian bank Islam, dan menjadi selebriti melalui siarannya di TV al-Jazeera (Soage, 2008: 54).

\section{Pengembangan cakupan harta zakat dalam pemikiran Yusuf al-Qaradawi}

Corak pemikiran al-Qaradawi sebagaimana diuraikan di atas sedikit banyak mempengaruhi model pemikirannya dalam masalah zakat yang akan dibahas di sini. Kriteria umum harta yang bisa dikenakan zakat menurut al-Qaradawi adalah: dimiliki penuh, berkembang (produktif), sampai nisab, kelebihan dari kebutuhan dasar, tidak ada hutang, dan telah dimiliki setahun penuh (al-Qaradawi, 1973: 127-166). Kriteria tersebut dapat dijadikan acuan dalam pengembangan cakupan harta zakat. Manakala suatu jenis harta memiliki keenam kriteria tersebut, maka ia dapat dimasukkan dalam kategori harta yang wajib dizakati. Sesungguhnya kriteria harta yang wajib dizakati sudah banyak dibahas di kitab-kitab fikih mazhab-klasik, seperti Bada'i' al-Sana'i', dan Fath al-Qadir (Fath al-Qadir, III: 460-499).

Milik sempurna adalah kepemilikan terhadap benda dan manfaatnya sekaligus (al-Zarqa', 1967: 258.) di mana pemiliknya dapat mentransaksikannya secara bebas untuk mendapatkan hasilnya. Oleh karena itu benda yang menjadi jaminan dalam akad gadai, misalnya, tidak terkena wajib zakat karena ia bukan merupakan benda dalam kepemilikan sempurna. Dasar 
dari ketentuan ini ada dua, yakni: di dalam nas Qur'an dan Sunnah harta yang diperintahkan untuk dikeluarkan zakatnya selalu dilekatkan dengan pemiliknya, ini bermakna kepemilikan (sempurna); dan penalaran logis, bahwa di dalam zakat terdapat unsur pemberian sebagian kepemilikan kepada para mustahiq untuk dimiliki mereka, bagaimana mungkin seseorang bisa memberikan miliknya jika ia sendiri tidak punya hak milik sempurna (al-Qaradawi, 1999 I: 131).

Adapun konsep produktif sebagai salah satu kriteria harta wajib zakat dalam pandangan al-Qaradawi dimaknai sebagai bertambah dengan beranak pinak dan dengan memperdagangkannya. Jadi harta yang produktif artinya harta yang dapat terus bertambah/ berkembang di kemudian hari. Zakat dikenakan terhadap harta yang produktif karena zakat itu sendiri maknanya adalah berkembang dan ia hanya dihasilkan dari harta yang berkembang (produktif). Jelasnya harta yang produktif adalah harta dikembangkan melalui kegiatan perdagangan atau peternakan. Perdagangan akan menghasilkan keuntungan, sementara peternakan akan menghasilkan susu, anak-keturunan, daging, dan sebagainya. Kriteria produktif ini didasarkan pada mafhum mukhlafah terhadap hadis Nabi:

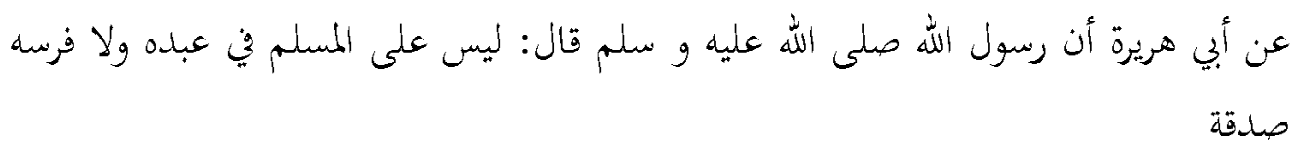

(al-Nisaburi, t.t. II: 675).

Menurut, al-Nawawi, sebagaimana dikutip oleh al-Qaradawi hadis tersebut menjadi dasar bahwa harta simpanan tidak dikenai zakat. Adapun harta yang produktif di negeri Arab meliputi: ternak (onta, sapi, dan domba); mata uang (dari emas dan perak); pertanian dan buah-buahan, termasuk madu; dan barang tambang dan rikaz (al-Qaradawi 1999: I: 141).

Nisab sebagai salah satu kriteria harta zakat maknanya adalah bahwa harta tersebut harus sudah mencapai jumlah tertentu sebagaimana yang diatur oleh syarak. Sebagaimana diketahui terdapat sejumlah hadis yang tidak mewajibkan zakat terhadap onta yang kurang dari lima ekor, kambing yang kurang dari 40 ekor, uang perak yang kurang dari 200 dirham, dan bijibijian, buah-buahan, serta hasil pertaniannya yang kurang dari 5 wasaq. Menurut al-Dahlawi, nisab-nisab tersebut mencerminkan kebutuhan hidup minimal satu keluarga (suami, istri, 
ljtihad: Jurnal Wacana Hukum Islam dan Kemanusiaan, Volume 17, No. 2, Desember 2017: 191-215

satu anak, dan satu pembantu) dalam setahun. Jumhur ulama berpandangan bahwa nisab berlaku pada semua harta zakat berdasarkan hadis:

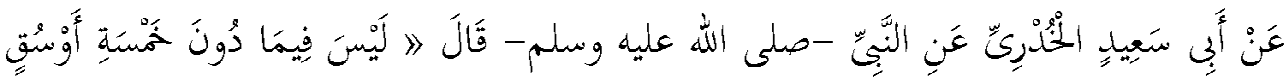

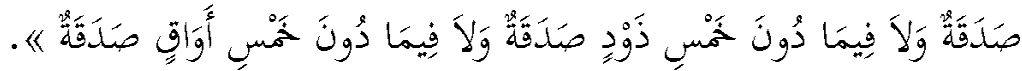

Muslim. Hadis no.66.

Zakat pada dasarnya sama dengan pajak yang dipungut dari orang kaya untuk membantu orang tak mampu atau untuk mewujudkan kemaslahatan dalam dalam masyarakat. Oleh karena itu ia hanya dikenakan kepada orang-orang mampu (kaya) sebagaimana hadis Nabi saw: (al-Qaradawi, 1973 I: 151).

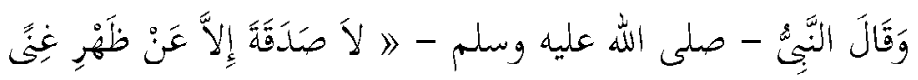

Adapun kriteria harta zakat sebagai harta lebih dari kebutuhan pokok, sebagian fukaha melekatkannya dengan ketentuan produktif (berkembang), maknanya adalah bahwa nisab merupakan kelebihan dari harta pemiliknya. Hal ini sebagaimana ditegaskan Mazhab Hanafi dalam kitab-kitabnya. Alasannya karena dengan kriteria inilah orang bisa dianggap kaya. Namun sebagian fukaha lainnya berpandangan bahwa ketentuan produktif pada harta tidak membutuhkan kriteria harta lebih dari kebutuhan pokok ini, karena tidak semua kebutuhan pokok tersebut merupakan harta produktif, seperti rumah yang ditinggali, kendaraan yang dipakai, dan pakaian yang dikenakan (al-Qaradawi, 1973 I: 152). Ketentuan lebih dari harta pokok ini didasarkan pada ayat dan hadis berikut:

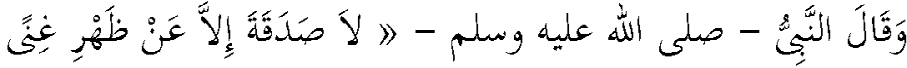

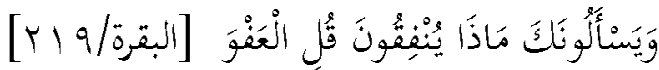

$$
\begin{aligned}
& \text { عن جابر قال: أعثق رجل من بني عزرة عبدا له عن دبر فبلغ ذلك رسول صلى الله عليه و }
\end{aligned}
$$

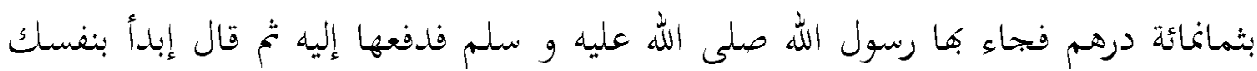$$
\text { سلم فقال ألك مال غيره فقال لا فقال من يشتريه مني ؟ فاشتراه نعيم بن عبدالله العدوي }
$$ 


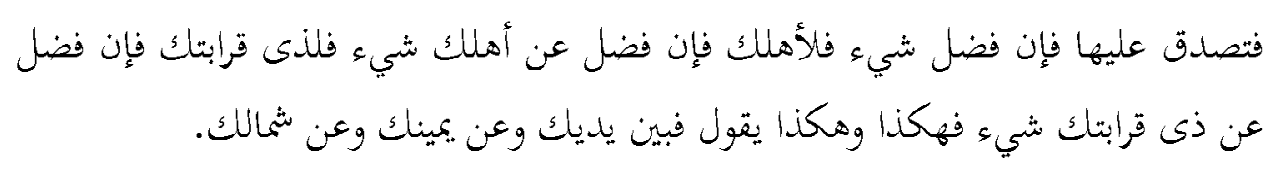

Kriteria berikutnya harta zakat adalah harta yang bebas dari hutang, artinya nisab harta terbebas dari hutang. Oleh karena itu jika pemilik harta memiliki hutang yang menghabiskan kadar nisabnya atau menguranginya maka ia tidak wajib zakat. Hanya saja para ulama berbeda pendapat terhadap harta zahir (harta yang kelihatan). Menurut Ibn Rusyd perbedaan tersebut bertitik tolak dari perbedaan paradigma di dalam memandang zakat, apakah ia merupakan ibadah semata atau merupakan hak orang miskin yang terkandung pada harta seseorang. Jika pandangan pertama yang digunakan maka tidak ada kewajiban zakat pada orang yang punya hutang, karena hak orang yang menghutangi harus didahulukan daripada hak orang miskin, di samping juga pada hakekatnya harta tersebut menjadi milik orang yang menghutangi. Akan tetapi jika zakat dianggap sebagai ibadah, maka pemilik harta terkena wajib zakat terhadap harta yang ditangannya, baik ia punya hutang ataupun tidak, karena syarat sudah terpenuhi. Di samping itu di dalam harta tersebut terdapat dua hak sekaligus, yakni hak Allah (ibadah) dan hak manusia (fakir miskin), di mana hak Allah lebih utama untuk dibayarkan. Menurut Ibn Rusyd, pendapat yang paling sesuai dengan tujuan syariat adalah bahwa gugurnya zakat dari orang yang berhutang (al-Qaradawi, 1973 I: 156).

Pandangan Ibn Rusyd tersebut pada dasarnya juga berlaku untuk semua jenis harta, baik zahir maupun batin (harta simpanan). Hal ini didasarkan pada argumen: Pertama, bahwa kepemilikan harta dari orang yang berhutang tidak kuat dan terbatas; Kedua, sesungguhnya pihak yang berpiutang wajib bayar zakat, sehingga jika pihak yang berhutang juga wajib zakat berarti terdapat kewajiban zakat dua kali pada satu harta, ini penggabungan yang terlarang dalam syarak; Ketiga, orang yang berhutang semestinya berhak menerima zakat (gharimin), bagaimana mungkin zakat diwajibkan kepada mustahiqnya; dan keempat, menurut hadis Nabi, zakat hanya diwajibkan kepada orang kaya, orang yang berhutang tentu tidak kaya, tetapi justru perlu dibantu untuk melunasi hutangnya (al-Qaradawi, 1973 I: 157).

Adapun kriteria hutang yang disepakati para ulama untuk mengugurkan zakat adalah hutang yang menghabiskan atau mengurangin kadar nisab harta dan tidak ada lagi hartanya selain itu (al-Qaradawi, 1973 I: 60). 
ljtihad: Jurnal Wacana Hukum Islam dan Kemanusiaan, Volume 17, No. 2, Desember 2017: 191-215

Haul sebagai kriteria harta zakat yang terakhir maknanya adalah bahwa harta tersebut telah mencapai satu tahun dimiliki oleh seseorang, yakni 12 bulan berdasarkan hitungan tahun Arab (Qamariyah). Ketentuan haul ini hanya berlaku untuk harta jenis ternak, uang, dan barang dagangan (dinamakan zakat harta pokok). Sementara harta jenis hasil tanaman, buah-buahan, hasil tambang, dan rikaz tidak dipersyaratkan haul (dinamakan zakat pendapatan). Rahasia ditetapkannya haul ini adalah untuk memantau produktivitasnya. Binatang ternak dipantau melalui perkembangbiakannya dan barang dagangan melalui keuntungannya agar mudah mengeluarkan zakatnya dari keuntungan tersebut. Adapun harta yang tidak dipersyaratkan haul adalah karena beragamnya bentuk dan kondisinya. Ketentuan haul terhadap ketiga jenis harta tersebut didasarkan pada praktik Khulafa' Rasyidun dan para sahabat, tidak ada perbedaan di antara mereka. Di samping itu terdapat riwayat marfu': (al-Qaradawi, 1973 I: 162).

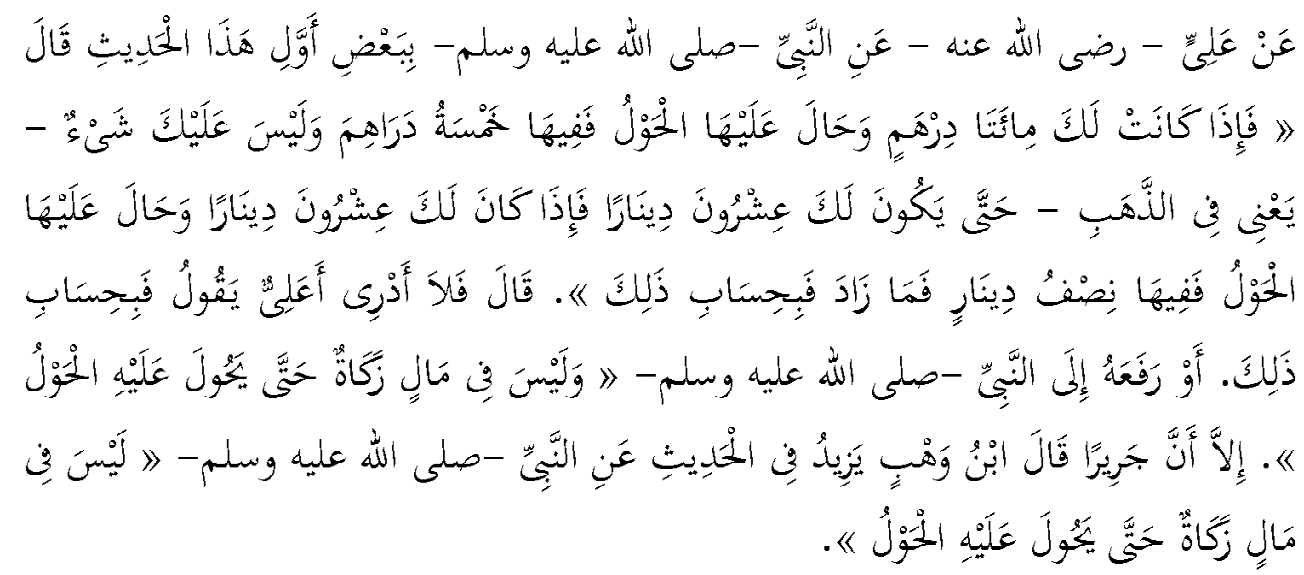

Al-Qaradawi kemudian mengutip pandangan Ibn Rusyd yang menyatakan bahwa ketentuan haul tersebut sudah diijmakkan oleh para fukaha dari berbagai kota. Tidak ada perselisihan megenai hal itu di kalangan ulama generasi awal kecuali riwayat dari Ibn 'Abbas, Ibn Mas'ud, dan Mu'awiyah. Mereka berpendapat bahwa harta wajib dizakati pada waktu didapatkan dan telah mencapai nisab tanpa mempersyaratkan haul. Pandangan ini didukung pula oleh sebagian tab'in. Penyebab perbedaan adalah karena tidak adanya hadis yang pasti berasal dari Nabi saw. Al-Qaradawi menegaskan bahwa yang disepakati para ulama salaf maupun khalaf adalah haul terhadap harta ra's al-mal, yakni binatang ternak, uang, dan barang 
dagangan, sehingga tidak terjadi pungutan zakat dua kali dalam setahun. Yang diperselisihkan oleh para ulama adalah harta mustafad (harta yang dimiliki dari ketiadaan sebelumnya, seperti gaji, dan yang semacamnya (al-Qaradawi, 1973 I: 167).

Paradigma pengembangan zakat al-Qaradawi terutama didasarkan pada postulat bahwa harta yang wajib dizakati adalah harta yang berkembang (produktif). Berbeda dengan sebagian penulis, seperti Wahbah al-Zuhayli, yang menyebutkan salah satu kriteria harta yang wajib dizakati adalah bahwa harta tersebut termasuk dalam kategori harta yang wajib dizakati; al-Qaradawi tidak menyebutkan kriteria semacam itu di dalam bukunya. Al-Zuhayli bahkan menegaskan di dalam bukunya bahwa harta yang wajib dizakati meliputi lima jenis, yakni: mata uang, tambang dan rikaz, barang dagangan, hasil bumi (pertanian), dan binatang ternak. (Al-Zuhayli, 1985 II: 740). Dari sini dapat dipahami bahwa kalau menurut al-Zuhayli jenis harta zakat sudah tertentu, sementara menurut al-Qaradawi jenis harta zakat dapat terus berkembang.

Al-Qaradawi menegaskan bahwa produktif sebagai syarat harta yang wajib dizakati didasarkan pada petunjuk Nabi saw dan praktik Khulafa` Rasyidun di mana hal itu ditunjukkan pula oleh arti zakat itu sendiri, yakni berkembang. Beberapa ayat berikut mengindikasikan akan hal itu: (al-Qaradawi, 1973 I: 142).

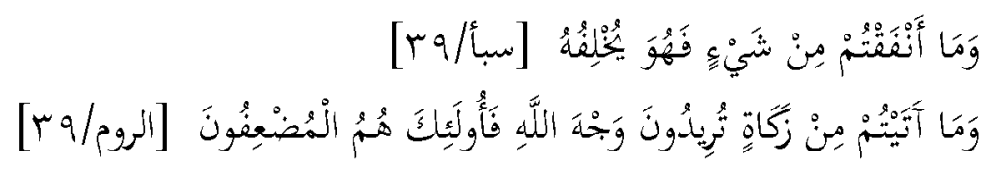

Para ulama menegaskan bahwa zakat hanya diwajibkan terhadap harta yang dikembangkan dan tidak wajib terhadap harta yang disimpan oleh pemiliknya, seperti harta ghasab, hilang, dan sebagainya. Mazhab yang paling ekstensif menggunakan kriteria berkembang (produktif) ini adalah Mazhab Maliki.

Menurut al-Qaradawi harta yang tidak produktif (tidak bisa dikembangkan) ada dua jenis: (al-Qaradawi, 1973 I: 145). Pertama, tidak bisa dikembangkan karena dirinya sendiri, seperti: harta ghasab yang tidak jelas keberadaannya, hutang yang tidak bisa diharapkan pelunasannya, dan harta terpendam yang lupa tempatnya. Harta jenis ini tidak dikenai kewajiban zakat. Kedua, tidak bisa berkembang disebabkan oleh pemiliknya sendiri. Harta jenis ini tetap dikenai kewajiban zakat, tanpa perlu dicari penyebabnya. Setiap muslim wajib untuk mengembangkan hartanya dengan berbagai cara yang dibenarkan oleh syarak, baik dilakukan 
ljtihad: Jurnal Wacana Hukum Islam dan Kemanusiaan, Volume 17, No. 2, Desember 2017: 191-215

sendiri ataupun melalui kerjasama usaha dengan orang lain. Ia tidak boleh lemah di dalam menjalankan usaha tersebut dan dalam menghilangkan bebagai hambatan yang menghadang. Di dalam Islam kelemahan tersebut bukanlah uzur syar'i yang dapat membebaskannya dari kewajiban membayar zakat, tetapi sebagai sifat yang tidak baik yang tumbuh dari kekurangan diri atau keburukan masyarakatnya.

Oleh karena itu al-Qaradawi menegaskan bahwa setiap harta yang bisa dikembangkan maka ia menjadi sumber pemungutan zakat atau terkena kewajiban zakat, kendati Nabi saw tidak pernah mewajibkan di dalam hadis-hadisnya terhadap harta benda tersebut, cukup dimasukkan dalam cakupan keumuman ayat dan hadis Nabi (al-Qaradawi, 1973 I: 145). Ia mengakui bahwa pandangannya ini berbeda dengan sebagian fukaha yang cenderung membatasi harta zakat, seperti Ibn Hazm dan yang lainnya yang membatasi harta zakat hanya pada jenis-jenis yang disebutkan dalam hadis-hadis Nabi. Di dalam al-Muballa Ibn Hazm membatasinya hanya pada delapan jenis, yakni: onta, sapi, domba, padi gandum, beras gandum, kurma, emas, dan perak. Jadi bagi Ibn Hazm kismis tidak dikenai zakat, kendati terdapat hadis tentang itu, hanya saja tidak diakuinya. Demikian pula harta dari golongan binatang, hanya tiga macam saja (onta, sapi, dan domba) yang dikenai zakat. Sementara dari golongan tanaman hanya gandum dan kurma saja, sedangkan dari golongan tambang dan mata uang hanya emas dan perak saja yang terkena wajib zakat. Adapun barang dagangan tidak terkena zakat sama sekali (al-Qaradawi, 1973 I: 146).

Di samping golongan yang cenderung membatasi harta zakat, sebagian fukaha ada pula yang cenderung mengembangkannya. Ulama fikih yang paling ekstensif dalam mewajibkan zakat adalah Abu Hanifah. Ia mewajibkan zakat pada setiap tanaman yang sengaja dikembangkan atau dibudayakan, bahkan tanpa mempersyaratkan nisab. Demikian pula terhadap binatang. Hanya saja ia tidak mewajibkannya kecuali hanya terhadap mukallaf. Oleh karena itu harta anak yang belum baligh dan orang gila tidak dikenai zakat (al-Qaradawi, 1973 I: 146).

Adapun pandangan Ibn Hazm tersebut dan sebagian ulama belakangan yang mendukungnya, seperti al-Syawkani dan Shiddiq Hasan Khan, didasarkan atas dua argumen. Pertama, haramnya harta seorang muslim, maka tidak boleh diambil sedikitpun kecuali atas dasar nas syarak. Kedua, zakat merupakan beban syarak. Pada dasarnya manusia terbebas dari segala beban syarak kecuali didasarkan pada nas, sehingga kita tidak dibebani kewajiban 
syarak kecuali sepanjang yang diijinkan oleh Allah. Adapun qiyas tidak bisa digunakan (dijadikan dasar) khususnya dalam hal zakat ini.

Dasar pemikiran Ibn Hazm dan sebagian ulama yang mengikutinya di atas disanggah oleh al-Qaradawi yang menegaskan bahwa harta zakat dapat terus berkembang dan diperluas sepanjang memenuhi kriteria yang ditentukan syarak sebagaimana telah disebutkan di atas. Adapun dasar argumen al-Qaradawi dalam hal ini adalah: (al-Qaradawi, 1973 I: 147). Pertama, ayat-ayat dan hadis-hadis Nabi saw secara umum menyatakan bahwa di dalam setiap harta terdapat hak orang lain, sedekah ataupun zakat, tanpa penjelasan harta mana atau yang seperti apa; sementara dari hadis-hadis Nabi dapat dipahami bahwa harta (mal) tersebut adalah yang berkembang (produktif), bukan harta yang digunakan untuk kehidupan sehari-hari. Oleh karena itu tidak boleh mengecualikan sebagian harta dari hak-hak tersebut tanpa didasari oleh dalil syarak, dan memang tidak ada dalil semacam itu. Kedua, setiap orang kaya perlu mensucikan hartanya melalui pembayaran infak, mensucikan dari sifat kikir dan individualis. Tidak masuk akal jika pensucian harta tersebut hanya dikenakan terhadap petani gandum yang kecil, sementara pemilik kebun buah-buahan yang luas dan pemilik perusahaan yang keuntungannya berlipat-lipat justru tidak terkena kewajiban tersebut. Ketiga, masih dalam konteks penyucian harta, ia hanya bisa disucikan dengan mengeluarkan zakatnya. Tidak logis jika pensucian tersebut hanya dibatasi pada delapan macam harta sebagaimana pandangan Ibn Hazm di atas, tidak berlaku terhadap harta lainnya, padahal sebagian harta tersebut justru menjadi sumber kekayaan utama masyarakat dan negara saat ini.Keempat, tujuan disyariatkannya zakat adalah untuk membantu fakir miskin dan mustabiq lainnya (delapan asnaf) memenuhi kebutuhannya. Kemaslahatan ini menjadi kewajiban setiap pemilik harta untuk mewujudkannya. Tidak logis jika kewajiban tersebut hanya dibebankan kepada mereka yang memiliki lima ekor onta, atau 40 ekor kambing, atau lima wasaq gandum, sementara para pemodal besar yang memiliki perusahaan-perusahaan besar, para dokter, dan para pejabat yang gaji seharinya bisa melampaui lima wasaq gandum justru tidak dikenai kewajiban tersebut. Kelima, menurut jumhur ulama qiyas merupakan salah satu dasar hukum syarak, kendati Ibn Hazm menyelisihinya. Oleh karena itu dalam pandangan al-Qaradawi qiyas dapat dilakukan terhadap setiap harta yang berkembang (produktif) pada saat ini dengan jenis-jenis harta zakat pada masa Nabi saw dan para sahabatnya. Diterapkannya qiyas terhadap 
ljtihad: Jurnal Wacana Hukum Islam dan Kemanusiaan, Volume 17, No. 2, Desember 2017: 191-215

zakat ini karena zakat bukan sekedar ibadah mahdah tetapi sistem ekonomi dan sosial dalam Islam.Keenam, Al-Qaradawi tidak menyangkal akan perlindungan terhadap harta seorang muslim dan hak khsusus yang dimilikinya terhadap hartanya, namun di sisi lain hak Allah (hak masyarakat) juga ada di dalam harta tersebut, demikian pula hak para fakir miskin. Ini semua juga ada dalam nas syarak.

Dalam analisis penulis argumen tersebut masih belum bisa menjawab pertanyaan mendasar bahwa konsep zakat pada awalnya merupakan semacam pajak yang diterapkan oleh Nabi dan para sahabatnya untuk menghimpun dana dari masyarakat dalam rangka membiayai operasional 'pemerintahan Islam' yang baru tumbuh. Oleh karena zakat atau 'pajak' tersebut sangat penting, karena menyangkut eksistensi Islam ke depan yang terlembaga melalui 'negara dan pemerintahan Islam', maka pemungutannya kemudian mendapatkan penguatan melalui otoritas keagamaan, diwajibkan Allah dalam al-Qur'an dan Sunnah Nabi saw. Oleh sebab itu kajian tentang zakat tidak bisa dipisahkan dari kajian tentang fiskal (pajak) (Basyir, 2011: 7-11).

Konstruk makna yang tergambar dari argumen tersebut adalah bahwa harta zakat dapat terus diperluas kepada setiap harta yang produktif, namun tidak jelas siapa yang berwenang memperluasnya dan menentukan kadarnya, batasan nisabnya, dan sebagainya (al-Qaradawi, 1973 : 747-791). Seakan-akan setiap ulama boleh berijtihad untuk menentukan harta jenis baru yang wajib dizakati dan serta merta menganggap orang yang tidak menzakatinya berdosa karena kelalalaian itu. Jika zakat dianggap sebagai ajaran tentang sistem ekonomi dan sosial maka semestinya ia diperlakukan lebih fleksibel dalam konteks pemerintahan, karena pemerintahan jelas memiliki banyak kewenangan dan kekuasaan terhadap warga masyarakat dalam hal ini. Zakat sebagai kewajiban kebendaan tidak akan mungkin efektif berjalan jika masih diserahkan pelaksanaannya kepada kesadaran individu. Ia butuh organ yang memiliki kekuasaan memungut, mengelola, menyalurkan, dan juga memperluasnya kepada hartaharta atau sumber-sumber penghasilan masyarakat yang terus berkembang. Konsep semacam ini di masyarakat modern sebenarnya sudah cukup terwakili dengan konsep pajak.

Di samping itu ambiguitas di dalam memahami ajaran zakat masih tampak jelas dalam argumen di atas, antara zakat sebagai ibadab mabdah dan sebagai sistem harta yang bersifat sosial (yang berkategori muamalah). Di satu sisi jenis-jenis harta zakat masih terus dipertahankan berdasarkan ketentuan nas (yakni sekitar delapan macam sebagaimana disebutkan oleh Ibn 
Hazm), tetapi pada sisi yang lain jenis-jenis harta tersebut ingin terus diperluas sebagaimana pemerintahan modern selalu ingin memperluas cakupan harta kena pajak. Ambiguitas antara zakat sebagai ibadah mahdah dan zakat yang dipandang sebagai ajaran hukum dalam bidanng muamalat (keduaniaan) menjadi problem tersendiri di dalam menerapkanya di zaman modern ini.

\section{Ambigu dalam memposisikan zakat antara ibadah mahdah dan muamalah}

Jika zakat diposisikan sebagai ajaran ibadah mahdah maka ia akan dianggap bersifat ghayr ma'qulah al-ma'na (unintelligible, tidak bisa dinalar), tertutup terhadap perubahan, dan tidak dapat dikembangkan. Oleh karena itu zakat hanya terbatas pada jenis harta yang secara jelas diatur dalam hadis-hadis Nabi saw. Jenis harta beserta ketentuan nisab dan kadar zakatnya tersebut jika diringkaskan sebagai berikut: (al-Zuhayli, 1985 : 758-845).

\begin{tabular}{|c|c|c|c|c|}
\hline No & Jenis Harta Benda & Nisab & Haul & Zakat \\
\hline 1 & Emas & 93,6 gram & setahun & $2,5 \%$ \\
\hline 2 & Perak & 624 gram & setahun & $2,5 \%$ \\
\hline 3 & $\begin{array}{l}\text { Hasil Pertanian } \\
\text { Atau Perkebunan }\end{array}$ & $653 \mathrm{~kg}$ & Waktu panen & $\begin{array}{ll}5 \% & \text { Dengan Teknologi } \\
10 \% & \text { Non - Teknologi }\end{array}$ \\
\hline 4 & Barang Perdagangan & 93,6 gram & Setahun & $2,5 \%$ \\
\hline 5 & Hasil Tambang & 93,6 gram & Selahun & $2,5 \%$ \\
\hline 6 & Mata Uang & 93,6 gram & Setahun & $2,5 \%$ \\
\hline 7 & Barang Temuan & $93,6 \mathrm{gram}$ & Waktu ditemukan & $20 \%$ \\
\hline 8 & $\begin{array}{l}\text { Binatang Ternak } \\
\text { a. Unta } \\
\text { b. Sapi/Kerbau } \\
\text { c. Kambinga }\end{array}$ & $\begin{array}{l}5 \text { ekor } \\
30 \text { ekor } \\
40 \text { ekor }\end{array}$ & $\begin{array}{l}\text { Setahun } \\
\text { Setahun } \\
\text { setahun }\end{array}$ & $\begin{array}{l}1 \text { ekor kambing bisa umur } 2 \text { tahun lebih; } \\
1 \text { ekor anak sapl, umur } 2 \text { tahun lebih } \\
1 \text { ekor kambing betina bisa umur } 2 \text { tahun }\end{array}$ \\
\hline
\end{tabular}

Tabel di atas sebagai gambaran umum saja. Jika mengacu pada pandangan Ibn Hazm, yang merepresentasikan pandangan yang ketat membatasi jenis-jenis harta yang dizakati, maka kedelapan jenis harta tersebut meliputi: onta, sapi, domba, padi gandum, beras gandum, kurma, emas, dan perak beserta nisab dan kadar zakatnya yang tergambar dalam tabel di atas. Dalam perspektif ibadah mahdah zakat hanya terbatas pada kedelapan jenis harta tersebut dan tidak bisa dikembangkan ataupun dimodifikasi. 
ljtihad: Jurnal Wacana Hukum Islam dan Kemanusiaan, Volume 17, No. 2, Desember 2017: 191-215

Akan tetapi jika zakat diposisikan sebagai ajaran hukum muamalah (keduniaan) maka ia akan dipandang bersifat ma'qulah al-ma'na (intelligible, bisa dinalar), terbuka terhadap perubahan maupun modifikasi, dan yang pasti bisa dikembangkan terus sesuai dengan perubahan zaman. Tidak hanya dalam hal jenis hartanya yang bisa dikembangkan dan disesuaikan dengan perubahan, tetapi semestinya juga pada ketentuan nisab dan kadar zakatnya, bahkan juga peruntukannya (masarif al-zakah) ataupun ketetuan-ketentuan lainnya, yang penting tetap sesuai dengan tujuan disyariatkannya zakat, yakni untuk membantu fakir miskin dan anggota masyarakat yang kurang mampu serta mewujudkan kesejahteraan sosial secara lebih luas, di satu sisi; dan mensucikan harta dan diri muz̧akki dari segala kekotoran pada sisi yang lain (alQaradawi, 1973 II: 898)

Ambiguitas al-Qaradawi tampak pada pandangannya di satu sisi bahwa zakat terhadap delapan jenis harta yang jelas diatur dalam nas syarak di atas tetap dipertahankan apa adanya, termasuk dalam hal nisab dan kadar zakatnya, dengan anggapan bahwa itu merupakan ketentuan syarak yang bersifat ta'abbudi sehingga tinggal terima jadi (taken for granted), tidak perlu dipersoalkan, sami'na wa ata'na. Akan tetapi pada sisis yang lain ia cenderung ingin mengembangkan terus cakupan jenis harta yang kena zakat berdasarkan enam kriteria sebagaimana telah diuraikan di atas sehingga seakan-akan zakat menjadi seperti pajak yang digunakan oleh pemerintah untuk meningkatkan pendapatan negara dengan terus memperluas cakupan benda atau harta kena pajak. Padahal ia selalu menegaskan bahwa zakat berbeda dengan pajak, tidak bisa disamakan di antara keduanya. Di samping itu ia juga sering menganalogikan konsep zakat dengan dengan pajak (al-Qaradawi, 1973 I: 151)

Jika dalam pandangannya zakat dan pajak memiliki banyak kemiripan, terutama fungsi sosialnya, yakni sama-ama untuk membantu kalangan tidak mampu dan untuk mewujudkan kemaslahatan yang lebih luas dalam masyarakat, kenapa ia tidak disatukan saja, zakat diintegrasikan dengan pajak, misalnya. Akan tetapi yang terjadi justru ia ingin mempertahankan keduanya berdiri sendiri. Pemikirannya seperti ini tentu tidak lepas dari ambiguitas pandangannya dalam melihat zakat tersebut, antara ibadah mahdah dan muamalah. Zakat harus dipertahankan orisinalitasnya, sehingga tidak mungkin digabung atau bahkan dilebur dengan pajak, karena ia dipandang sebagai ibadah mabdab; tetapi zakat juga perlu terus dikembangkan karena ia merupakan ajaran sosial (muamalah) yang menuntut untuk selalu dinamis. 


\section{Zakat dipisahkan dari konteks sosial-politik-sejarah}

Sebenarnya zakat mal telah diwajibkan sejak permulaan Islam sebelum Nabi saw hijrah ke Madinah. Pada awalnya zakat diwajibkan tanpa ditentukan kadarnya dan tidak pula ditentukan jenis-jenis harta yang diwajibkan zakat. Syariat hanya memerintahkan mengeluarkannya, banyak sedikitnya diserahkan kepada masing-masing pembayar zakat. Hal ini berlangsung hingga tahun kedua Hijriyah ketika syarak mulai menentukan macammacam harta yang wajib dizakati beserta kadarnya masing-masing. Adapun mustahiq zakat pada masa itu hanya dua golongan saja yaitu fakir dan miskin. Pembagian zakat kepada dua golongan tersebut berlangsung hingga tahun ke-9 Hijriyah di mana pada waktu itu Allah menurunkan ayat 60 Surat al-Taubah yang berisi ketentuan tentang delapan asnaf mustabiq zakat. Namun demikian Nabi sendiri tidak selalu membagi zakat kepada delapan asnaf tersebut, tetapi hanya kepada golongan yang perlu saja sesuai situasi (Shiddieqy, 2009: 8-10).

Zakat pada awal sejarah Islam diterapkan dan dilaksanakan oleh pemerintahan Islam demikian pula pada masa setelah itu. Zakat waktu itu merupakan sumber utama keuangan negara. Pada masa Nabi, Abu Bakar, Umar, dan pertengahan masa Usman, zakat dipungut oleh negara. Tetapi pada masa pertengahan kedua pemerintahan Usman para muzakki disuruh membayar sendiri, karena pada saat itu negara telah makmur dan untuk memungut zakat dirasakan terlalu banyak makan waktu dan tenaga. Namun zakat harta hasil pertanian dan binatang ternak masih dipungut oleh negara. Pada saat itu ia mendelegasikan kewenangan menaksir harta zakat kepada pemiliknya sendiri yang bertujuan untuk mengamankan zakat dari berbagai gangguan oleh beberapa oknum petugas pengumpul zakat. Di samping itu ia hanya mengenakan zakat terhadap harta setelah dikurangi hutang-hutangnya (Karim, 2012: 80).

Indikasi zakat sebagai instrumen negara dalam menggali dana dari warganya dapat dipahami dari konsep 'amil zakat itu sendiri. Yang dimaksud dengan 'amil adalah setiap orang yang terlibat dalam penyelenggaraan zakat, baik petugas pemungutnya, pencatatnya, petugas pendistribusiannya, dan seterusnya. Mereka semua mendapatkan upah dari harta zakat yang terkumpul. Perhatian al-Qur'an terhadap 'amil tersebut, dengan menyebutnya dalam ayat sebagai golongan mustahiq zakat pada urutan ketiga setelah fakir dan miskin, di mana mereka bertiga ini merupakan sasaran pendistribusian zakat yang paling utama, menunjukkan bahwa zakat dalam Islam bukan tugas individual semata tetapi merupakan 
ljtihad: Jurnal Wacana Hukum Islam dan Kemanusiaan, Volume 17, No. 2, Desember 2017: 191-215

bagian dari tugas pemerintah untuk menjalankannya melalui organ yang dibutuhkan seperti petugas pemungutnya, pencatatnya, petugas pendistribusiannya, dan seterusnya dengan menggaji mereka dari harta zakat (al-Qaradawi, 1973 II: 579).

Para fukaha umumnya menegaskan tentang wajibnya penguasa untuk mengangkat petugas pemungut zakat $(s \bar{a} \bar{\imath})$ karena Nabi saw dan para khalifah sesudahnya menugaskan para $s \bar{a} \bar{i}$ tersebut. Urgensi penugasan kepada mereka itu adalah karena tidak semua orang yang punya harta mengetahui bahwa di dalam hartanya tersebut ada zakatnya dan mereka yang tahu akan kewajiban tersebut sebagiannya tidak mau mengeluarkan, maka para para $s \bar{a} \bar{i}$ tersebut ditugaskan untuk memungutnya. Pemerintah perlu mengangkat petugas zakat untuk memungut zakat pertanian dan buah-buahan (yakni yang tidak dipersyaratkan baul) dan menugaskan pada para sa' $\bar{i}$ untuk memungut zakat ternak dan harta lain yang yang mempersyaratkan haul. Hendaknya mereka menentukan bulannya dalam mendatangi muzakki dan disukai Bulan Muharram karena ia merupakan bulan awal menurut syarak. Dalam konteks ini terdapat beberapa riwayat yang menguatkannya (al-Qaradawi, 1973 II: 580)

Dengan konstruk pemahaman bahwa zakat pada awal Islam dan juga masa-masa sesudahnya merupakan sumber keuangan negara dan secara formal ditangani oleh pemerintah maka bisa dipahami manakala zakat dalam pelaksanaannya terus mengalami pengembangan dan modifikasi dari waktu ke waktu. Dalam konteks ini pemerintah memiliki otoritas untuk mengembangkan dan memperlua cakupan harta zakat. Bahkan tidak hanya bekenaan dengan cakupan harta kena zakat yang mengalami perluasan, tetapi juga pada aspek-aspek lainnya seperti besaran zakat dan pengeloalaannya. Akan tetapi al-Qaradawi kurang memberikan perhatian pada aspek ini sehingga terkesan bahwa pengembangan zakat yang ia tekankan tersebut seolah-olah bisa dilakukan oleh siapa saja, tidak harus negara. Al-Qaradawi bahkan menyatakan bahwa karena zakat merupakan kewajiban agama yang sakral dan telah tertanam kuat dalam hati umat Islam serta diterapkan sepanjang sejarah mereka, maka zakat wajib dipertahankan kekhasannya di samping zakat, seperti namanya, jenis-jenisnya, kadarnya, dan pentasarufannya. Ia juga menegaskan bahwa setiap pribadi muslim wajib melaksanakan zakatnya sendiri manakala pemerintah tidak mewajibkannya (al-Qaradawi, 1973 II: 1111)

Jika pengembangan cakupan harta zakat tersebut bisa dilakukan oleh lembaga-lembaga swasta - seperti Lazismu, Lazisnu, dan Dompet Du’afa untuk kasus di Indonesia — atau 
lembaga semi pemerintah tetapi dengan kewenangan terbatas, seperti BAZNAS, atas dasar apa mereka mewajibkan harta-harta baru yang dipungut zakatnya? Jika atas dasar legitimasi keagaman melalui ijtihad, maka akan dengan mudah disanggah bahwa menurut teori hukum Islam ijtihad tidaklah mengikat orang lain untuk mengikutinya. Berbeda halnya jika penyelenggara zakat adalah pemerintah, pengembangan cakupan harta zakat yang kemudian diwajibkan kepada masyarakat yang memenuhi kriteria untuk mengeluarkan zakatnya tentu saja didasarkan atas kewenangan pemerintah untuk menetapkan kewajiban-kewajiban tertentu berkenaan dengan harta. Atas dasar kewenangan tersebut pemerintah juga memiliki kewenangan untuk memaksa warga masyarakat yang tidak mematuhinya.

\section{Zakat harus berbeda dengan pajak}

Al-Qaradawi berpandangan bahwa zakat berbeda dengan pajak, meskipun ia tidak menolak adanya kewajiban pajak di samping zakat. Menurutnya ada tiga ciri pokok zakat yang membedakan dengan pajak, yakni: kadarnya (besaran zakat), niatnya (ibadah), dan sasaran pentasarufannya (delapan asnaf). Atas dasar itulah al-Qardawi menolak untuk menyamakan zakat dengan pajak sekaligus mengkritik sebagian ulama yang cenderung menyamakan keduanya, seperti: Imam Nawawi, Imam Ahmad ibn Hanbal, dan Ibn Taymiyyah. Pada saat yang sama ia mendukung pandangan ulama yang tegas membedakan zakat dengan pajak, seperti: Ibn Hajar al-Haysami, Ibn 'Abidin, Syekh 'Ulaysy, Syekh Sayyid Rasyid Rida, Syekh Syaltut, dan Syekh Abu Zahrah (al-Qaradawi, 1973 II: 1113).

Dengan demikian dapat disimpulkan bahwa al-Qaradawi cenderung memisahkan kajian zakat dari konteks kenegaraan karena baginya zakat tetap harus dilaksanakan oleh setiap muslim kendati negara tidak mewajibakannya dan zakat harus dipertahankan kekhasannya sampai kapanpun. Demikian ini pulalah kajian zakat yang berkembang saat ini di Indonesia, yakni mengabaikan konteks kenegaraannya. Kajian tentang zakat yang semacam itu cenderung hanya menekankan pada aspek ketentuan formalnya, seperti cakupan harta zakat, nisab, dan kadar zakat, tanpa mengaitkannya dengan konteks sosial kesejarahannya sebagai bagian dari instrumen pemerintah/negara dalam menghimpun dana dari masyarakat untuk membiayai pelaksanaan tugas negara mewujudkan kemaslahatan dalam masyarakat. Zakat yang tadinya menjadi tanggungjawab negara untuk menghimpun, mengelola, menyalurkan, dan 
ljtihad: Jurnal Wacana Hukum Islam dan Kemanusiaan, Volume 17, No. 2, Desember 2017: 191-215

mengembangkannya kemudian beralih kepada sebagian atau segolongan umat Islam untuk menjalankannya. Dalam konteks Indonesia zakat ditangani oleh lembaga-lembaga amil zakat di luar pemerintah, seperti Lazismu, Lazisnu, dan Dompet Duafa atau lembaga semi pemerintah seperti BAZNAS.

Lembaga-lembaga tersebut tentu saja berbeda dengan lembaga pemerintahan yang menyelenggarakn zakat pada masa awal Islam tersebut, terutama berkenaan dengan kewenangan memungut dan pentasarufannya. Dalam hal yang pertama, lembaga amil zakat jelas tidak memiliki kewenangan untuk memungut paksa dari muzakki yang tidak patuh. Berbeda dengan pemeritahan Islam awal yang memiliki petugas pemungut zakat (sầ) yang diberi kewenngan untuk memungut paksa jika muzakki membangkang. Sementara dalam hal yang terakhir, pentasarufan zakat, pemerintah saat ini justru tidak memiliki kewenangan mentasarufkan dana zakat tersebut sesuai dengan keinginannya, karena pentasarufan menjadi kewenangan eksklusif lembaga amil tersebut. Oleh karena itu dalam konteks penghimpunan dana dan penyalurannya dari dan untuk masyarakat, 'amil zakat hidup dalam dunianya sendiri dengan zakat yang dipungut dan kemudian disalurkannya; sementara pemerintah pun juga hidup dengan dengan dunianya dengan pajak yang dipungut dan kemudian dibelanjakannya.

Jika diasumsikan cakupan harta zakat terus diperluas sehingga penerimaan zakat pun menjadi semakin besar maka pentasarufan zakatnya pun juga akan mengalami perluasan. Semua aspek kehidupan sosial dapat saja dibantu oleh dana-dana zakat yang sudah sedemikian besarnya dalam rangka mewujudkan kemaslahatan bersama dalam masyarakat. Jika demikian skenarionya apakah hal itu justru tidak tumpang tindih dengan kewenangan dan kebijakan pemerintah dalam memungut dan menyalurkan pajak. Manakala dua institusi yang berbeda menangani bidang yang sama biasanya yang terjadi justru inefisiensi dan ketidakmerataan distribusi. Oleh karena itu, penyatuan zakat dan pajak sesungguhnya lebih logis. Gagasan yang kemudian menjadi kebijakan pemerintah beberapa waktu yang lalu untuk menjadikan pembayaran zakat dari masyarakat dapat dijadikan sebagai pengurang pajak bukanlah solusi yang tuntas terhadap dualisme zakat dan pajak yang dialami oleh umat Islam Indonesia.

Solusi yang komprehensif terhadap dualisme zakat dan pajak yang dialami umat Islam Indonesia yang ditawarkan penulis adalah dengan mengintegrasikan zakat kepada pajak. Kongkritnya adalah menghapuskan kewajiban zakat formalumat Islam Indonesia dengan 
pertimbangan bahwa mereka sebagai warga negara telah dibebani kewajiban membayar pajak kepada pemerintah/negara. Jadi kewajiban zakat dalam konteks umat Islam Indonesia telah termanifestasikan dalam pajak yang mereka bayarkan kepada pemerintah. Dengan ungkapan lain pajak yang mereka bayarkan tersebut sudah cukup menggantikan kewajiban zakat dalam agama mereka. Pandangan ini didasarkan pada pokok-pokok pemikiran sebagai berikut: Pertama, zakat pada masa Nabi dan para khalifah sesudahnya pada hakekatnya adalah pajak juga jika dilihat dari perspektif saat ini. Hal ini ditunjukkan oleh berbagai riwayat dan tarikh yang menunjukkan bahwa pensyariatan zakat di kalangan umat Islam adalah dalam konteks penyelenggaraan pemerintahan (negara). Kedua, ayat-ayat zakat dalam Qur'an perlu dipahami sebagai bentuk penguatan perintah kepada umat Islam agar mau membayar zakat, karena komunitas umat Islam pada masa Nabi — di mana sebagian ahli menyebutnya sebagai negara Islam — yang sedang tumbuh membutuhkan dana zakat (pajak) tersebut untuk mempertahankan eksistensinya. Nabi membutuhkan dana-dana yang terkumpul dari masyarakat (terutama dari zakat) untuk menyelenggrakan pemerintahan yang sedang berusaha mengokohkan eksistensinya. Ketiga, dalam konteks saat ini di Indonesia ayat zakat tersebut dapat ditransformasikan menjadi dalil tentang wajibnya umat Islam membayar pajak di manapun ia hidup, karena pajak (zakat) merupakan bentuk partsisipasi nyata dari setiap warga negara untuk memperkuat pemerintahannya di dalam menyelenggarakan segala bentuk pelayanan dan perlindungan kepada setiap warganya. Jadi dalam konsep zakat ini tersirat kewajiban imbal balik antara warga negara atau masyarakat dengan pemerintahannya (negara). Masyarakat diwajibkan membayar zakat (pajak) karena mereka mendapatkan pelayanan umum dan jaminan keamanan dari pemerintah. Dari sisi yang lain pemerintah atau negara wajib memberikan pelayanan umum dan jaminan kemanan yang baik bagi warga masyarakatnya karena mereka telah membayar zakat (pajak). Keempat, zakat pada dasanya adalah kewajiban kebendaan yang bersifat sosial (non-ibadah). Sebagai sebuah kewajiban sosial ia tidak mungkin diserahkan kepada lembaga swasta yang tidak memiliki kewenangan untuk memaksa. Sebagaimana kewajiban menjatuhkan sanksi pidana tertentu, seperti potong tangan bagi pencuri yang juga ada perintahnya dalam al-Qu'an, meniscayakan adanya pemerintahan yang berwenang untuk mengeksekusi vonis pidana tersebut. Tidak mungkin ia diserahkan kepada lembaga swasta di luar pemerintah untuk melaksanakannya. Kelima, 
ljtihad: Jurnal Wacana Hukum Islam dan Kemanusiaan, Volume 17, No. 2, Desember 2017: 191-215

memahami zakat tidak bisa dilepaskan dari konteksnya, yakni penyelenggraan pemerintahan (negara). Pemahaman terhadap zakat yang terpisah dari konteks tersebut, sebagaimana umumya saat ini, menjadikan banyak aspek dari zakat yang tidak dapat berjalan sebagaimana mestinya, seperti kewenangan memungut paksa dan mengembangkan cakupan harta zakat. Hal-hal semacam ini menjadi muncul karena kekeliruan kita dalam memahami zakat, yakni melepaskannya dari konteks kenegaraan.

\section{Penutup}

Konstruk argumen pengembangan cakupan harta zakat dalam pemikiran Yusuf al-Qaradawi dapat dibedakan menjadi dua yakni yang bersifat umum dan khusus. Argumen umumnya didasarkan atas teori qiyas dan maslahah, sementara argumen khusus didasarkan pada teori dalam fikih zakat itu sendiri, yakni yang berkenaan dengan kriteria harta zakat. Dari enam kriteria yang ia sebutkan ia kemudian mengembangkan salah satunya yakni harta yang produktif (berkembang). Atas dasar kriteria ini maka banyak harta jenis baru yang bisa tercakup menjadi harta zakat, seperti harta-harta yang diperoleh dari saham perusahaan, ternak madu, dan profesi. Tentu saja harta-harta baru yang ia sebutkan sekedar sebagai contoh saja. Di masa yang akan datang dapat terus bertambah sesuai dengan perkembangan kehidupan umat Islam.

Argumen pengembangan cakupan harta zakat tersebut dapat disanggah melalui tiga argumen: Pertama, ambiguitas al-Qaradawi dalam menempatkan ajaran tentang zakat antara ajaran ibadah mahdah dan ajaran muamalab/'adah (keduniaan). Ambiguitas menyebabkan inkonsistensi dalam pemikiran. Jika zakat diposisikan sebagai ajaran dalam ranah 'adah/ muamalab semestinya ketentuan-ketentuan tentang zakat bisa dibuat fleksibel, sedemikian rupa sehingga bisa diintegrasikan dengan pajak. Tetapi justru ia tegas menekankan kekhasan zakat sebagai ajaran ibadah yang harus dipertahankan dan tidak bisa disamakan dengan pajak. Jadi ia memposisikan zakat sebagai ajaran 'adah/mu'amalab tetapi paradigma ibadah mahdah-nya masih kuat dipegangnya. Kedua, Al-Qaradawi cenderung memisahkan kajian zakatnya dari konteks historis di mana kewajiban zakat di masa Nabi dan para khalifah sesudahnya selalu terkait dengan kehidupan kenegaraan/pemerintahan. Ketiga, Al-Qaradawi menekankan bahwa zakat berbeda dengan pajak dan di antara keduanya tidak bisa disatukan. 
Padahal dalam pembahasannya ia sering menganalogikan zakat dengan pajak. Di samping itu secara historis zakat juga semacam pajak yang diwajibkan oleh agama untuk menopang komunitas umat Islam yang sedang tumbuh agar dapat mengokohkan eksistensi mereka. Oleh karena itu ajaran zakat saat ini bisa dianggap sebagai ajaran tentang wajibnya umat Islam untuk membayar pajak kepada pemerintah/negara tempat ia hidup sebagai imbalan dari pelayanan umum dan jaminan keamanan yang diberikan oleh pemerintah kepada dirinya sebagai warga negara.

\section{Daftar pustaka}

Abdurrahman, KHE. Menempatkan Hukum dalam Agama. Bandung: Sinar Baru, 1990.

Anshori, Abdul Ghofur. Hukum dan Pemberdayaan Zakat: Upaya Sinergis Wajib Zakat dan Pajak di Indonesia. Yogyakarta: Pilar Media, 2006.

Abdurrahman, Asjmuni. Pengantar kepada Ijtihad. Jakarta: Bulan Bintang, 1978.

Abu Muhammad, 'Ali ibn Ahmad ibn Hazm al-Andalusi. "Al-Muhalla bi al-Asar Syarh alMujalla bi al-Ikhtisar," dalam al-Maktabah al-Syamilah al-Isdar al-Sani.

Al-Azdi, Sulayman ibn al-Asy'as Abu Dawud al-Sijistani. Sunan Abi Dawnd, tahqiq: Muhammad Muhy al-Din 'Abd al-Hamid. Ttp.: Dar al-Fikr, t.t.

Aziz, Jamal Abdul. Dikotomi Tbadat dan 'Adat dalam Hukum Islam. Yogyakarta: Grafindo, 2009.

'Azzam, 'Abd al-'Aziz Muhammad. Al-Qawa'id al-Fiqhiyyah. Kairo: Dar al-Hadis, 2005.

Bakri, Asafri Jaya. Konsep Maqashid Syariah Menurut Al-Syatibi. Jakarta: P.T. Raja Grafindo Persada, 1996.

Bakry, Hasbullah. Pedoman Islam di Indonesia. Jakarta: UI-Press, 1990.

Basyir, Ahmad Azhar. Keuangan Negara dan Hisbah dalam Islam. Yogyakarta: UII-Press, 2011. Bernand, M. "Mu'amalät” dalam The Encyclopaedia of Islam, ed. C.E. Bosworth, et.al. LeidenNew York: E.J. Brill, 1993.

Al-Bukhari, Muhammad ibn Isma'il Abu 'Abd Allah. Al-Jam' al-Sahih al-Mukhtasar, tahqiq: Mustafa Dib al-Bigha. Beirut: Dar Ibn Kasir, 1987.

Chalil, K.H. Moenawar. Kembali kepada al-Qur'an dan as-Sunnah. Jakarta: Bulan Bintang, 1999. Al-Dahlawi, Syah Waliyullah ibn 'Abd al-Rahman. Hujjat Allah al-Balighah. Kairo: Dar alTuras, t.t.

Al-Dimasyqi, Abu al-Fida' Isma'il ibn 'Umar ibn Kasir al-Qurasyi. Tafsir al-Qur'an al-'Azim, muhaqqiq: Sami ibn Muhammad Salamah. Ttp.: Dar Tayyibah li al-Nasyr wa al-Tawzi', 1999. 
ljtihad: Jurnal Wacana Hukum Islam dan Kemanusiaan, Volume 17, No. 2, Desember 2017: 191-215

Hafidhuddin, Didin. Zakat dalam Perekonomian Modern. Jakarta: Gema Insani Press, 2002. Hallaq,Wael. "From Fatwas to Furu': Growth and Change in Islamic Substantive Law," dalam An Anthology of Islamic Law Studies, ed. Howard M. Federspiel. Montreal: McGill Institute of Islamic Studies, 1996.

Hassan, Ahmad. Soal Jawab Masalah Agama, 4 jilid. Bangil: Percetakan Persatuan, 1985.

Helfont, Samuel. Yusuf al-Qaradawi: Islam and Modernity. Tel Aviv: The Moshe Dayan Center, 2009.

Karim, Adiwarman. Sejarah Pemikiran Ekonomi Islam. Jakarta: P.T. RajaGrafindo Persada, 2012.

Khallāf, 'Abd al-Wahhāb. 'Ilm al-Ușül al-Fiqh. Al-Kuwayt: Dār al-Qalam, 1978.

Masud, Muhammad Khalid. Filsafat Hukum Islam: Studi tentang Hidup dan Pemikiran Abu Ishaq Al-Syatibi, terj. Ahsin Muhammad. Bandung: Pustaka, 1996.

Al-Nawawi. "Syarh al-Nawawi 'ala Muslim," dalam al-Maktabah al-Syamilah al-Isdar al-Sani.

Al-Nisaburi, Muslim ibn al-Hajjaj Abu al-Husyan al-Qusyayri. Sabib Muslim, tahqiq: Muhammad Fu'ad 'Abd al-Baqi. Beirut: Dar Ihya' al-Turas al-'Arabi, t.t.

Padwick, Constance E. "Muslim Devotions: A Study of Prayer Manuals in Common Use". Dalam An Anthology of Islamic Studies, ed. Howard M. Federspiel. Montreal: McGill Insstitute of Islamic Studies, 1996, II: 13-19.

Qardawi, Yusuf. Fiqh al-Zakāh: Diräsab Muqāranah li Aḥkāmihā wa Falsafatihā fi Daw" alQur'an wa al-Sunnah. Beirut: Mu'assasah al-Risalah, 1973.

. Hukum Zakat: Studi Komparatif Mengenai Status dan Filsafat Zakat Berdasarkan Qur'an dan Hadis, terj. Salman Harun dkk. Bogor: Pustaka Litera Antar Nusa, 2011.

. Taysir al-Fiqh lil Muslim al-Mu'asir fi Daw' al-Qur'an wa al-Sunnah. Kairo: Maktabah Wahbah, 2004.

- Al-Sabwah al-Islamiyyah Bayna al-Ikbtilaf al-Masyru' wa al-Tafarruq al-Mazmum. Kairo: Dar al-Syuruq, 2001. - Al-Figh al-Islami Bayna al-Asalah wa al-Tajdid Kairo: Maktabah Wahbah, 1999.

Ash Shiddieqy, T.M. Hasbi. Pedoman Zakat. Semarang: Pustaka Rizki Putra, 2009. Pengantar Hukum Islam. Jakarta: Bulan Bintang, 1981.

Al-Suyuti, Jalal al-Din 'Abd al-Rahman ibn Abi Bakr. Al-Asybah wa al-Naza'ir. Semarang: Toha Putra, t.t.

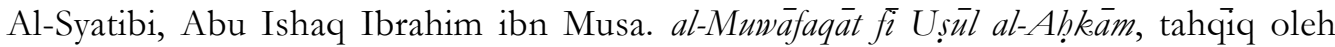
Muḥammad Muḥy al-Din 'Abd al-Ḥamid, 4 jilid. Kairo: Muhammad 'Ali Ṣabị wa Awlāduh, t.t. 
Rayner, S.E. The Theory of Contracts in Islamic Laws: A Comparative Analysis with Particular Reference to the Modern Legislation in Kuwait, Babrain, and the United Arab Emirates. London/Dordrecht/Boston: Graham and Trotman, 1991.

Soage, Ana Belen. "Shaykh Yusuf al-Qaradawi: Portrait of Leading Islamic Cleric," dalam Middle East Review of International Affairs, Vol. 12 No. 1 (Maret 2008).

Al-Zarqa', Mustafa Ahmad. Al-Fiqh al-Islami fi Sawbih al-Jadid: al-Madkhal al-Fiqhi al-'Amm. Damaskus: Alif Ba'al-Adib, 1967.

Al-Zuhayli, Wahbah. Al-Fiqh al-Islami wa Adillatuh, 9 jilid. Damaskus: Dar al-Fikr, 1985. 
